\title{
Effect Of Spiritual Emotional Freedom Technique (SEFT) On The Decrease In Anxiety Levels In Cancer Patients
}

\author{
Dewi Musfira Hasal ${ }^{*}$, Muriyati², Nadia Alfira ${ }^{3}$ \\ S1 Nursing Study Program, Stikes Panrita Husada Bulukumba, Indonesia ${ }^{1}$ \\ Departemen Surgical Medical Nursing ,Stikes Panrita Husada Bulukumba, Indonesia2,3
}

*Corresponding Autor : Email: Dewimusfira23@gmail.com

\begin{abstract}
According to WHO 2013 data, every year the number of cancer patients in the world increases, the incidence of cancer is increasing from 12.7 million cases in 2008 to 14.1 million cases in 2012. The diagnosis of cancer is daunting for the patient and can affect the patient's psychological conditions especially anxiety. This anxiety is common because of the financial problems, diseases of symptoms, concerns about healing, concerns that can not run function as humans maximally, and may affect the prognosis of disease that should be good, but becomes otherwise. The harassment of nonfarmochalate anxiety is by distraction and relaxation one of them is a SEFT. This study aims to determine the effect of the theft of SEFT therapy on the decline of anxiety in cancer patients. Research methods using experimental pre-design by using the type of One Group Pre test post test design, with purposive sample technique and using tpaired test of wilcoxon test alternative. The results of the research obtained that the level of anxiety of respondents before the seft therapy is the average anxiety is as much as 11 people (73.3\%). While the rate of anxiety of respondents after the seft therapy is the average of light weight anxiety as many as 14 people (93.3\%). From the results of the Wilxocon test is obtained there is the effect of giving the seft to the decrease in anxiety level in cancer patients with value $\rho$ value $=0,002(\rho<0.05)$. Conclusion of this research is there is an enhanced influence between the spiritual therapy of the Emotional Freedom Technique (Seft) to the decline in anxiety level in cancer patients at Griya Al-Afiat clinics.
\end{abstract}

Keywords: Seft Therapy, Anxiety, Cancer

\section{INTRODUCTION}

Cancer is a term that encompasses a complex group of different types of cancer. Cancer can affect almost every organ in the human body. Cancer is a disease caused by impaired control of the regulation of normal cell growth.(Subagja, 2014). In the world, cancer is the number 2 cause of death after cardiovascular disease. An estimated 7.5 million people die from cancer, and more than $70 \%$ of deaths occur in poor and developing countries. According to 2013 WHO (World Health Organization) data, every year the number of cancer patients in the world increases, the incidence of cancer increased from 12.7 million cases in 2008 to 14.1 million cases in 2012.(Riset Kesehatan Dasar, 2013). 
Nationally the prevalence of cancer in the population of all ages in Indonesia in 2013 amounted to $1.4 \%$ or estimated at about 347,792 people. D.I. Yogyakarta province has the highest prevalence for cancer, which is $4.1 \%$. Based on the estimated number of cancer patients in Central Java province and East Java province is the province with the most estimated cancer patients, which is about 68,638 and 61,230 people. While the provinces of West Sumatra, East Kalimantan, North Sulawesi and south Sulawesi are ranked 5 th with prevelence of cancer patients by 1.7\%.(INFODATIN, 2015). Then based on the results of Riskesdas 2018 that cases of cancer in south Sulawesi decreased with a prevalence of 1.6\%.(RISKESDAS, 2018).

Anxiety is an unclear and diffuse worry related to feeling uncertain and helpless. This emotional state has no obvious object, but can be measured from physiological responses to anxiety from both the cardiovascular, respiratory, neuromuscular, gastrointestinal, germination and skin systems.(Yolanda and Karwur, 2013).

Anxiety reactions in a cancer patient often appear not only when the patient is diagnosed with cancer, but also when the patient undergoes chemotherapy. This anxiety is common because of financial problems, anxiety when symptoms are felt, concerns about healing, and worries about not being able to perform their functions as women to the fullest. In cases of cancer patients who will undergo medical treatment (surgery, chemotherapy, etc.) show expressions that reflect anxiety and depression, negativistic attitudes (rejection) and cause many cases that should have a good prognosis, but become the opposite.(Pratiwi et al., 2017).

SEFT (Spiritual Emotional FreedomTechnique) is a combination of techniques that use psychological energy and spiritual power and prayer to overcome negative emotions. SEFT directly deals with "disruption of the body's energy system" to eliminate negative emotions by realigning the body's energy system. SEFT is effective in overcoming stress because there are several therapeutic techniques that are summarized and practiced simply, these therapies include do'a, NLP (Neuro Linguistic Programming), hypnotherapy, visualization, meditation, relaxation, imagery and desensitisas (Desmaniarti and Avianti, 2014).

Research supporting the effectiveness of SEFT has been conducted by Ningsih (2015) With significant differences between anxiety scores before and after EFT therapy. In addition, research Desmaniarti and Avianti (2014), With the results of the 
study showed SEFT can reduce the stress of cervical cancer patients undergoing chemotherapy.

Based on the results of research conducted at the Al-Afiat healthy griya clinic, 11 out of 15 existing respondents experienced moderate anxiety due to the symptoms of the disease, the treatment process and the impact of surgery or medical treatment. The purpose of this study was to find out if there was an effect of spiritual emotional freedom technique (SEFT) on the decrease in anxiety levels in cancer patients at Griya Sehat Al-Afiat Clinic.

\section{MATERIAL AND METHODS}

The research design used in this study is pre experimental design using one group pre test post test design type of research.(Lapau, 2012), It aims to find out if there is an effect of spiritual emotional freedom technique (SEFT) therapy on the decrease in anxiety levels in cancer patients at Griya Sehat Al-Afiat Clinic. Population is a generalization area consisting of: objects / subjects that have certain qualities and characteristics set by researchers to be studied and then drawn conclusions.(Sugiyono, 2017). The population of this study was cancer patients at Griya Sehat Al-Afiat Clinic as many as 30 people. This research sampling technique uses non probability techniques with purposive sampling methods, which are sampling techniques with certain considerations (Sugiyono, 2017).

The number of samples in the study was 15 respondents. The research instrument used in this study is to use the HARS (Hamilton Anxiety Rating Scale) kusioner guidelines as a measuring instrument. Kusioner guidelines (angket) is a data collection technique that is done by giving a set of questions or written statements to respondents for answering(Sugiyono, 2017). Data is analyzed based on measuring scale and research objectives using computerized program software. Data analyzed in: (1). Univariate analysis, Analysis is conducted to determine the anxiety level of cancer patients before and after therapy. (2). Bivariate analysis, bivariate test is performed to look for influence between independent variables and dependent variables with the test used is t-pair when qualified, and will be performed Wilcoxon test as alternativ. The confidence interval taken is $95 \%$ and the meaningful limit received when $\mathrm{p}<0.05$. 


\section{RESULTS}

Table 1. Characteristics of the research subject

\begin{tabular}{lcc}
\hline \multicolumn{1}{c}{ Characteristic } & Frequency $(\mathrm{f})$ & Persentase (\%) \\
\hline Gender & 3 & 20.0 \\
\hline Male & 12 & 80.0 \\
Female & & \\
\hline Age & 3 & 20.0 \\
\hline Early adulthood (26-35) & 2 & 13.0 \\
late adulthood (36-45) & 8 & 53.3 \\
Early Elderly (46-55) & 2 & 13.3 \\
Late Elderly (56-65) & & \\
\hline Education & 12 & 80.0 \\
\hline School & 3 & 20.0 \\
No School & & \\
\hline Marital status & 15 & 100.0 \\
\hline Marry & 0 & 0 \\
Not Married & & \\
Work & 4 & 26.7 \\
Work & 11 & 73.3 \\
Does not work & & \\
\hline Medical diagnosis & 11 & 73.3 \\
\hline CA. Mammae & 1 & 6.7 \\
CA. Brain & 1 & 6.7 \\
CA. Lungs & 1 & 6.7 \\
CA. Stomach & 1 & 6.7 \\
CA. Bone & & \\
\hline Disease duration & 1 & 6.7 \\
\hline 5 month & 6 & 6.7 \\
12 month & 1 & 20.0 \\
18 month & 4 & 100.0 \\
24 month & 3 & 6.7 \\
60 month & 15 & \\
\hline Amount & & \\
\hline
\end{tabular}

Based (table 1) shows the distribution of respondents' frequency based on gender, age, education, marital status, employment, medical diagnosis and length of illness. The number of respondents in this study was 15 respondents. Characteristics of the study include gender, age, education, occupation, marital status, medical diagnoses, and length of illness. The gender of respondents was female (80\%), the age of respondents was the initial elderly 46-55 years (53.3\%), the respondent's education was school (80\%), the respondent's job was not working (73.3\%), the respondent's marital status was married (100\%), the respondent's medical diagnosis was ca. Mammae (73.3\%), and the length of the respondent's illness was 12 months (40\%). 
Table 2. Anxiety levels before seft therapy

\begin{tabular}{ccc}
\hline Anxiety Level & Frequenscy (f) & Percentage (\%) \\
\hline No Worry & 0 & 0 \\
Mild Anxiety & 4 & 26.7 \\
Moderate Anxiety & 11 & 73.3 \\
\hline Amount & 15 & 100 \\
\hline
\end{tabular}

Based (table 2) shows the frequency distribution of anxiety levels prior to SEFT therapy. Of the 15 respondents who experienced anxiety there were 11 people $(73.3 \%)$ who were moderately anxious, and 4 people (26.7\%) who were mildly anxious, and none of the respondents were not anxious.

Table 3. Anxiety levels after SEFT therapy

\begin{tabular}{ccc}
\hline \hline Anxiety Level & Frekuensi (f) & Persentase (\%) \\
\hline No Worry & 0 & 0 \\
Mild Anxiety & 14 & 93.3 \\
Moderate Anxiety & 1 & 6.7 \\
\hline Amount & 15 & 100 \\
\hline \hline
\end{tabular}

Based (table 3) shows the frequency distribution of anxiety levels after SEFT therapy. Of the 15 respondents who experienced anxiety there were 14 people (93.3\%) who were mildly anxious, and 1 person (6.7\%) who were moderately anxious, and none of the respondents were not anxious.

Table 4. Effect of SEFT therapy on decreased anxiety levels

\begin{tabular}{|c|c|c|c|c|c|}
\hline \multirow{2}{*}{$\begin{array}{l}\text { Anxiety Level } \\
\text { No Worry }\end{array}$} & \multicolumn{2}{|c|}{ Pre } & \multicolumn{2}{|c|}{ Post } & \multirow{2}{*}{$\rho$ Value } \\
\hline & f & $\%$ & f & $\%$ & \\
\hline Mild Anxiety & 0 & 0 & 0 & 0 & \multirow{4}{*}{0,002} \\
\hline Moderate Anxiety & 4 & 26.7 & 14 & 93.3 & \\
\hline Anxiety Level & 11 & 73.3 & 1 & 6.7 & \\
\hline Amount & 15 & 100 & 15 & 100 & \\
\hline
\end{tabular}

Based (table 4) shows an analysis of the influence of Spiritual Emotional Freedom Technique (SEFT) therapy on decreased anxiety levels in cancer patients. The Wilcoxon trial, with a result of $\rho$ value $=0.002(\rho<0.05)$, showed that there was an effect of spiritual emotional freedom technique (SEFT) on the decrease in anxiety levels in cancer patients.

\section{DISCUSSION}

Based on the results of the study conducted showed that there was an influence of spiritual emotional freedom technique (SEFT) therapy on the decrease in anxiety levels in cancer patients at Griya Sehat Al-Afiat Clinic. With the wilcoxon test results obtained the value $p=0.002(p<0.05)$. SEFT interventions have a mixture of engineering 
elements including neuro linguistic program (NLP), psychoanalysis, and hypnosis techniques performed during the therapy process. This technique can help identify the presence of anxiety and can overcome anxiety that occurs in patients based on the main root problems through the set up process carried out. The source of the anxiety is what will be used as an afrmasi sentence when tapping.(Shari, 2014).

At the time of tapping, the patient is in a state of relaxation. The impact of doing relaxation is that it can decrease the activity of sympathetic nerves that can cause the rhythm of breathing to be slow, blood pressure to drop, so as to lower the heart's oxygen consumption. The state of relaxation also affects the patient's mental condition and lowers muscle tension due to decreased hormones adrenaline and cortisol, so that heart rate, high blood pressure and muscle tension decrease, thus causing a comfortable atmosphere and lowering feelings of anxiety.(Haruyama, 2015).

Bougea et al (2013), It is mentioned that by specifically stimulating the acupuncture points have an influence in the production of $\beta$-endorphins. The basic theory of SEFT therapy reveals that all causes of negative emotions are due to disturbances in the body's meridian energy system. Tapping techniques that are manually administered to meridian points in the body have an influence in regulating activity in the limbic system by producing opioids, serotonine and GABA in the amygdala and improving cortisol regulation. The expenditure of this hormone is what suppresses the production of glucocorticoids so that this hormone can make tapping done during SEFT therapy, so as to reduce patient anxiety.

This research is in accordance with the results of the study.Bakara et al (2013) Seft interventions can significantly lower levels of depression, anxiety and stress in SKA (Acute Coronary Syndrome) patients. According to the researchers' assumptions, there is a significant influence between Spiritual Emotional Freedom Technique (SEFT) therapy on the decrease in anxiety levels because SEFT therapy utilizes the body's energy system to improve the state of the human mind, emotions and behavior. Where at the time of this therapy given by the tune-up method is aimed at the flow of energy our body is directed appropriately. This step is done to neutralize psychological reversal (psychological thoughts in the form of spontaneous negative thoughts or negative subconscious beliefs, tune-in that aims to make a person be sincere and resigned to what has happened and tapping is a technique of emphasis on some spots of silence on the body, then the respondent is relaxed and in a comfortable position as possible. 
The relaxed condition can affect the patient's psychological condition, and make the symptoms of anxiety reduced including respondents feeling unsettled, respondents can sleep soundly and no longer often experience waking up in the middle of the night and urinating in the middle of the night, and lowering muscle tension. So one of the effective management of anxiety is spiritual emotional freedom technique (SEFT) therapy.

\section{CONCLUSIONS AND SUGGESTIONS}

Based on the results of the study it is known that there is a meaningful influence between spiritual emotional freedom technique (SEFT) therapy and decreased anxiety levels in cancer patients in Griya Al-Afiat clinic. The results of this study are expected to increase knowledge for students at STIKES Panrita Husada Bulukumba. And nurses as a method for anxiety management are related to find out how the effect of Spiritual Emotional Freedom Technique (SEFT) therapy on decreased anxiety levels is not only in cancer patients, both for sick and healthy people who experience anxiety.

\section{REFERENCE}

Bakara, D.M., Ibrahim, K., Sriati, A., 2013. Efek Spiritual Emotional Freedom Techniqueterhadap Cemas dan Depresi, Sindrom Koroner Akut. J. Keperawatan Padjadjaran 1.

Bougea, A.M., Spandideas, N., Alexopoulos, E.C., Thomaides, T., Chrousos, G.P., Darviri, C., 2013. Effect of the emotional freedom technique on perceived stress, quality of life, and cortisol salivary levels in tension-type headache sufferers: a randomized controlled trial. Explore J. Sci. Heal. 9, 91-99.

Desmaniarti, Z., Avianti, N., 2014. Spiritual Emotional Freedom Technique (SEFT) menurunkan Stres Pasien Kanker Serviks. J. Ners Vol 9, 91-96.

Haruyama, S., 2015. The Miracle of Endorphin. Penerbit Qanita.

INFODATIN, 2015. status penyakit kanker. Kementrian Kesehatan RI, Jakarta Selatan.

Lapau, B., 2012. Metode penelitian kesehatan : metode ilmiah penulisn Skripsi,. Yayasan Pustaka Obor Indonesia, Jakarta.

Ningsih, S.F., Karim, D., Sabrian, F., 2015. Efektivitas Terapi Emotional Freedom Technique (EFT) Terhadap Kecemasan Pasien Kanker Payudara Stadium II Dan III. JOM Vol. 2.

Pratiwi, S.R., Widianti, E., Solehati, T., 2017. Gambaran Faktor-Faktor yang Berhubungan dengan Kecemasan Pasien Kanker Payudara dalam Menjalani Kemoterapi. J. Pendidik. KEPERAWATAN Indones. 3, 167-174. 
Riset Kesehatan Dasar, 2013. Badan Penelitian Dan Pengembangan Kesehatan Kementerian Kesehatan RI.

RISKESDAS, 2018. Hasil Utama Riskesdas. Kementrian Kesehatan.

Shari, W.W., Suryani, S., Emaliyawati, E., 2014. Emotional Freedom Techniques dan Tingkat Kecemasan Pasien yang akan Menjalani Percutaneous Coronary Intervention. J. Keperawatan Padjadjaran 2.

Subagja, H.P., 2014. Waspada!!! Kanker-Kanker Ganas Pembunuh Wanita, 1st ed. FlashBook, Yogyakarta.

Sugiyono, 2017. Metode penelitian kuantitatif, kualitatif, dan R\&D. Alfabeta, CV, Bandung.

Yolanda, A.E., Karwur, F.F., 2013. Tingkat Kecemasan Pasien Kanker Serviks pada Golongan Ekonomi Rendah yang Mengikuti Program Kemoterapi di RSUD Dr. Moewardi The level of Anxiety in Cervical Cancer Patients of Lower Socioeconomic Status Receiving Chemoteraphy in RSUD Dr. Moewardi. Sains Med. 5, 68-81. 